\title{
Awareness on breast self examination among reproductive age women
}

\author{
Sarita Shrestha, ${ }^{1}$ Sharda Chhetri, ${ }^{2}$ Jenny Napit $^{3}$ \\ ${ }^{1}$ Nepalese Army Institute of Health Science College of Nursing, Kathmandu, ${ }^{2}$ Alka Institute of Medicine \\ Science, Lalitpur, ${ }^{3}$ College of Medical Sciences, Chitwan
}

\author{
Correspondence \\ Ms. Sarita Shrestha \\ Nepalese Army Institute of \\ Health Science College of \\ Nursing, Kathmandu \\ Email: \\ sakulstha@gmail.com \\ DOI: http://dx.doi.org/10.3126/ \\ jemsn.v13i4.18731
}

Orcid ID: orcid.org/0000-0002 -2762-971X

Article received: Nov $21^{\text {st }} 2017$ Article accepted: Dec $13^{\text {th }} 2017$

\begin{abstract}
Background \& Objectives: Breast self-examination (BSE) is an inspection by a woman of her breasts to detect breast problem and cancer. The objective of the study was to identify awareness on breast selfexamination among the reproductive age women. Materials \& Methods: A descriptive study was carried out to find out the awareness on Breast Self-Examination among Reproductive Age Group Women in Kusunti, Lalitpur. 50 women ( 20 to 45 years) were selected by using purposive sampling technique. Semi structured interview questionnaire was used for data collection. Results: This study showed that more than three fourth respondents $(78 \%)$ said breast cancer is growth of extra lump in breast. More than three fourth respondents $(82 \%)$ said diagnosis of breast cancer in early stage by BSE and only $10 \%$ of respondents had knowledge about diagnosing by mammogram. Nearly three fourth $(72 \%)$ of the respondents had knowledge about meaning of BSE. More than half of the respondents $(60 \%)$ got the information from health workers. One fourth of the respondents $(32 \%)$ said that they don't know about palpation in circular motion. Conclusion: Based on the findings, it is concluded women have awareness on BSE but least only know how to perform it in step wise and majority of women neglects in practicing in period basis. It is recommended that further awareness program should be conducted to fulfill the gap on BSE.
\end{abstract}

Key words: Awareness; breast self examination; reproductive age women.

Citation: Shrestha S, Chhetri S, Napit J. Awareness on breast self examination among reproductive age women. JCMS Nepal. 2017;13(4):425-9.

\section{INTRODUCTION}

Breast self-examination (BSE) is screening method used to detect early breast cancer. The method involves the woman herself looking at and feeling each breast for possible lumps, distortions or swelling. It is more common in young and premenopausal women. ${ }^{1}$

Nearly 1.7 million new breast cancer cases were diagnosed in 2012. Breast cancer is the second most common cancer in women and men worldwide. In 2012 , it represented about $12 \%$ of all new cancer cases and $25 \%$ of all cancers in women. Breast cancer is the most frequently diagnosed cancer among women in 140 of 184 countries worldwide.
Globally, breast cancer now represents one in four of all cancers in women. Since 2008, worldwide breast cancer incidence has increased by more than $20 \%$. Mortality has increased by 14 percent. $^{2}$ According to American cancer society, women should do monthly self-examination of the breast at the age of 21 years for early detection of the breast cancer. As earlier breast cancer is found and diagnosed, the better chance of treating it effectively. That is why BSE is useful health care practice for early detection of breast cancer. A woman's risk of breast cancer approximately doubles if she has a first degree relative (mother, sister and daughter) who has been diagnosed with 
breast cancer. About $15 \%$ of women who get breast cancer have a family member diagnosed with it. In 2011, there were more than 2.6 million breast cancer survivors in the US. About one in eight U.S women will develop invasive breast cancer over the course of her life time. ${ }^{3}$

Breast cancer is the second most common malignancy among women in Nepal. It is more common in young premenopausal. The breast cancer management in Nepal is a little different compared with the developed countries. The reasons are socioeconomic status, lack of education and lack of facilities. Although cancer care is on the rise in Nepal, the optimal facility for centers managing breast cancer has to be improved significantly. Cancer education, screening and early detection are the key elements to influence the diagnosis, treatment and prognosis of breast cancer in Nepal. Breast cancer awareness and clinical breast examination are important tools for early detection in our resource limited context. Breast cancer can be cured in majority of the cases if diagnosed in early stages. ${ }^{4}$

\section{MATERIALS AND METHODS}

The design of the research study was descriptive. The study was conducted at Kusunti, Lalitpur. The populations were women of age group (20 to 45 years) from Pancheswor Mahila Jagaran Kendra. Non- probability purposive sampling techniques were used to select samples. Data was collected within three weeks. The total sample size 50 was selected for the study. Data was collected by using face to face interview technique using semistructured questionnaire. Permission was taken from the head of the Kendra. The respondents were explained about the purpose of the research and verbal consent was taken before involving them into the interview. Confidentiality of the participants was maintained in the study. The data collected was edited and coded carefully. Statistical package for social sciences (SPSS 18.0 version) was used for data entry and analysis of the data. The data were analyzed by using simple descriptive i.e. mean, frequency and percentage to describe variables.

\section{RESULTS}

Almost one third (32\%) of the respondents were 40 years and lowest $(8 \%)$ of the respondents was age between 25 to 29 yrs. The respondents mean age was 35 years. Regarding ethnicity, Brahmin was in majority with $66 \%$ of the total respondents. Lowest $4 \%$ of the respondents were Newar. Almost one fourth $(24 \%)$ of the respondents had completed the primary and secondary level, where as $20 \%$ of the

Table 1: Respondents' Awareness on Breast Cancer $(n=50)$

\begin{tabular}{|lcc|}
\multicolumn{1}{c}{ Variables } & Frequency & Percent \\
\hline $\begin{array}{l}\text { Meaning of Breast Cancer } \\
\text { Finding any abnormalities of breast }\end{array}$ & 2 & 4.0 \\
\hline Ulcer in breast & 2 & 4.0 \\
\hline Growth of extra lump in breast & 39 & 78.0 \\
\hline Finding cancer cell in breast tissue & 7 & 14.0 \\
\hline $\begin{array}{l}\text { Diagnosing breast cancer at early stage * } \\
\text { Breast Self Examination }\end{array}$ & 41 & 82.0 \\
\hline Breast Examination by physician & 28 & 56.0 \\
\hline Mammogram & 5 & 10.0 \\
\hline Biopsy & 6 & 12.0 \\
\hline Sign and Symptoms of Breast Cancer* & & \\
\hline Painless abnormal growth in breast & 41 & 82.0 \\
\hline Change in size and shape & 39 & 78.0 \\
\hline Change in skin color & 31 & 62.0 \\
\hline Abnormal blood mixed discharge from nipple & 36 & 72.0 \\
\hline Enlargement of axilary lymph node & 40 & 80.0 \\
\hline Multiple Responses & & \\
\hline
\end{tabular}


Table 2: Respondents' Awareness on Breast Self Examination (BSE) (n=50)

\section{Variables}

Meaning about BSE Meaning about BSE

Examination of own breast to check any abnormalities

Examination done by health personnel to check abnormalities

Examination for checking breast size only

Examination for roughly palpate breast

\section{Get Information On BSE}

Health Worker

Friends

Media

Need of BSE

To find out a lump or problem on breast at early stage

To find out shape, size and abnormalities

Helps to maintain good health

To find out any changes of breast and nipple

Appropriate Time for BSE in Pre-menopausal Women

Before menstruation period

During menstruation period

7-10days after the first day of the menstrual period has stopped

Whenever I remember I do

Appropriate Time for BSE in Post menopausal Women

On the fixed day of each month

Any time

Don't know

Times for Examine Breast per Month

One time

Two time

Seldom

Knowledge in Performing BSE *

Observe the changes occurred in size and shape

Observe the sign of discharge

Palpate in circular motion of breast

Check all the parts of breast

* Multiple Responses

respondents were higher secondary level and 18\% of the respondents was graduate level education. More than half $(64 \%)$ respondents were completely home maker, $12 \%$ were involved in business and $14 \%$ respondents were employed.

Table 1 reveals that regarding the meaning of breast cancer, $39(78 \%)$ of the respondents stated growth of extra lump in breast. More than three fourth $82 \%$ of the respondent's state breast self-examination is the method of diagnosing breast cancer at early stage and least number of respondents $10 \%$ said

Frequency Percent

72.0

12.0

2.0

14

7

60.0

4.0

36.0

18

66.0

6.0

22.0

6.0

$3 \quad 6.0$

$\begin{array}{ccc} & 4 & 8.0 \\ \text { stopped } & 1 & 2.0 \\ & 40 & 80.0 \\ & 5 & 10.0 \\ & 32 & 46.0 \\ 6 & 12.0 \\ & 12 & 24.0 \\ & 37 & 74.0 \\ 6 & 12.0 \\ 7 & 14.0\end{array}$

45

90

40

80

32

64

50

100 mammogram is a diagnosing method of breast cancer at early stage. Regarding the sign and symptoms of breast cancer, more than three fourth $(82 \%)$ of the respondents answered painless abnormal growth in breast, seventy eight percent (78\%) of the respondents answered change in size and shape of the breasts.

Table 2 shows that meaning of BSE, Almost three fourth $(72 \%)$ of the respondents understood its correct meaning as examination of own breast to check any abnormalities. More than half $(60 \%)$ of 
the respondent's state health workers as source of information on Breast Self Examination followed by media was thirty- six percent (36\%). Almost two -third $(66 \%)$ of the respondents answered need of BSE is for to find out a lump or problem on breast at early stage. Four- fifth $(80 \%)$ of the respondents gave answer as 7-10days after the first day of the menstrual period is an appropriate time for BSE in pre menopausal women. More than four fifth (90\%) of the respondents observe the changes occurred in size and shape during BSE. Whereas 64\% respondents palpate breast in circular motion.

\section{DISCUSSION}

This study reveals that regarding the meaning of breast cancer, $78 \%$ of the respondent's state growth of extra lump in breast. More than $82 \%$ of the respondent's state breast self-examination is the method of diagnosing breast cancer at early stage and least number of respondents $10 \%$ said mammogram is a diagnosing method of breast cancer at early stage. This finding was inconsistence with the study conducted in Nigeria by Olugbenga et $\mathrm{al}_{5}$ revealed that $91.6 \%$ knew breast self-examination, $93.2 \%$ knew clinical breast examination and only $32.8 \%$ knew mammography as a screening method. Regarding the sign and symptoms of breast cancer, more than three fourth $(82 \%)$ of the respondents answered painless abnormal growth in breast, seventy eight percent (78\%) of the respondent knew that change in size and shape. This findings are nearly supported with study of Maqsood et $\mathrm{al}^{6}{ }^{6}$ show that $(84 \%)$ respondents had heard of breast cancer, while $65 \%$ knew at least one major sign or symptom of breast cancer. Eighty five percent of respondents believed that early detection of cancer improved survival.

Regarding meaning of BSE, almost three fourth $(72 \%)$ of the respondents understood its correct meaning as examination of own breast to check any abnormalities. This finding is inconsistent with the study was conducted by $\mathrm{Yoo}$ et $\mathrm{al}_{7}$ showed that $88.0 \%$ women said that they had heard of BSE. It may be due to that the women were not aware in doing breast self-examination. More than half $(60 \%)$ of the respondents state health workers as source of information on Breast Self-Examination. This finding is inconsistence with the study was conducted by Simi et al. in Iran which showed that $49.4 \%$ who performed BSE learned it from medical personnel. $^{8}$ Thirty- six percent $(36 \%)$ of the respondents said the source of information was media. This finding is contradictory with the study was conducted by Yoo et $\mathrm{al}^{7}$ revealed that $87 \%$ respondents said their most common source of information on BSE was the media such as TV, radio and newspapers. It may be due to national health center not focus in Prevention on breast cancer through media. Government has not provided any health education programme to aware in breast self-examination for women through media.

Almost two-third $(66 \%)$ of the respondents answered need of BSE is for to find out a lump or problem on breast at early stage, whereas twenty two percent $(22 \%)$ of the respondents were said that it helps to maintain good health. Four- fifth $(80 \%)$ of the respondents gave answer as seven to 10 days after the first day of the menstrual period is an appropriate time for BSE in pre-menopausal women. Almost two third (64\%) of the respondents answered that appropriate time for BSE in postmenopausal is on the fixed day of each month where as $12 \%$ respondents said anytime for perform BSE. This finding is contradictory with the study was conducted by Oladimeji et $\mathrm{al}^{9}$ showed that $61.7 \%$ women strongly agreed that BSE is a method of screening for breast cancer. $36.3 \%$ reported that the best time for a woman to perform BSE was 'anytime'.

Nearly three fourth (74\%) of the respondent responded correctly about times for examine breast per month i.e. one time. This finding is contradictory with the study was conducted in Cameron by Suh et $\mathrm{a}^{10}$ revealed that $35 \%$ reporting performing BSE monthly and $12.5 \%$ performing it six monthly. More than four fifth (90\%) of the respondents observe the changes occurred in size and shape during BSE. Whereas (64\%) respondent palpate breast in circular motion. Similar study conducted by Nde et $\mathrm{al}^{11}$ finding was inconsistent with this study Very few $(9.0 \%)$ of the respondents actually knew how to perform BSE.

\section{CONCLUSION}

Based on the findings, it is concluded that respondents were aware on breast self-examination but confused on time and BSE performing in circular movement. Most of the respondents have no awareness in mammogram for screening breast cancer. Women are ignoring on performing BSE due to lack of details knowledge on disease and due to lack of awareness. 
More extensive awareness programme on breast self-examination should be provided by educational package among reproductive age group women to prevent breast cancer and reduce women morbidity and mortality rate.

\section{REFERENCES}

1. Kösters JP, Gøtzsche PC. Regular self $\square$ examination or clinical examination for early detection of breast cancer. Cochrane Database Syst Rev. 2003;(2):CD003373. https:// doi.org/10.1002/14651858.CD003373. PMID:12804462.

2. World Cancer Research Fund International. Breast cancer statistics / Breast cancer research foundation 2012. [cited 2017 Aug 12] Available from: https://www.bcrf.org/breastcancer-statistics.

3. American Cancer Society. Breast Cancer statistics 2012. Atlanta: American Cancer Society, Inc.

4. Singh YP, Saiyami P. Management of breast cancer in Nepal. J Nepal Med Assoc. 2009 Jul-Sep;48(175):252-7. PMID: 20795469.

5. Olugbenga-Bello A, Oladele EA, Bello TO, Ojo JO, Oguntola AS. Awareness and breast cancer risk factors: perception and screening practices among females in a tertiary institution in Southwest Nigeria. Niger Postgrad Med J. 2011 Mar 1;18(1):8-15. PMID: 1445107.

6. Maqsood B, Zeeshan MM, Rehman F, Aslam F, Zafar A, Syed B, Qadeer K, Ajmal S, Imam SZ. Students' Corner Breast Cancer Screening Practices and Awareness in Women admitted to a Tertiary Care Hospital of Lahore, Pakistan. JPMA. 2009;59(418).

7. Yoo BN, Choi KS, Jung KW, Jun JK. Awareness and practice of breast self-examination among Korean women: results from a nationwide survey. Asian Pacific Journal of Cancer Prevention. 2012;13(1):123-5. PMID: 22502653

8. Simi A, Yadollahie M, Habibzadeh F. Knowledge and attitudes of breast self examination in a group of women in Shiraz, southern Iran. Postgraduate medical journal. 2009 Jun 1;85(1004):283-7. PMID: 19528300.

9. Oladimeji KE, Tsoka-Gwegweni JM, Igbodekwe FC, Twomey M, Akolo C, Balarabe HS, Atilola O, Jegede O, Oladimeji O. Knowledge and beliefs of breast selfexamination and breast cancer among market women in Ibadan, South West, Nigeria. PloS one. 2015 Nov 25;10 (11):e0140904. journal.pone. 0140904 .

10. Suh MA, Atashili J, Fuh EA, Eta VA. Breast selfexamination and breast cancer awareness in women in developing countries: a survey of women in Buea, Cameroon. BMC research notes. 2012;5:627. https:// doi.org/10.1186/1756-0500-5-627. PMID: 23140094.

11. Nde FP, Assob JC, Kwenti TE, Njunda AL, Tainenbe TR. Knowledge, attitude and practice of breast self-examination among female undergraduate students in the University of Buea. BMC research notes. 2015 Feb 15;8(1):43. https:// doi.org/10.1186/s13104-015-1004-4. 